\title{
Formation and chemical aging of secondary organic aerosol during the $\beta$-caryophyllene oxidation
}

\author{
A. Tasoglou ${ }^{1}$ and S. N. Pandis ${ }^{1,2,3}$ \\ ${ }^{1}$ Department of Chemical Engineering, Carnegie Mellon University, Pittsburgh, USA \\ ${ }^{2}$ Department of Chemical Engineering, University of Patras, Patra, Greece \\ ${ }^{3}$ Institute of Chemical Engineering Sciences (ICE-HT), FORTH, Patra, Greece \\ Correspondence to: S. N. Pandis (spyros@ andrew.cmu.edu)
}

Received: 12 October 2014 - Published in Atmos. Chem. Phys. Discuss.: 20 November 2014

Revised: 14 April 2015 - Accepted: 28 April 2015 - Published: 2 June 2015

\begin{abstract}
The secondary organic aerosol (SOA) production during the oxidation of $\beta$-caryophyllene by ozone $\left(\mathrm{O}_{3}\right)$ and hydroxyl radicals $(\mathrm{OH})$ and the subsequent chemical aging of the products during reactions with $\mathrm{OH}$ were investigated. Experiments were conducted with ozone and with hydroxyl radicals at low $\mathrm{NO}_{x}$ (zero added $\mathrm{NO}_{x}$ ) and at high $\mathrm{NO}_{x}$ (hundreds of parts per billion). The SOA mass yield at $10 \mu \mathrm{g} \mathrm{m}^{-3}$ of organic aerosol was $27 \%$ for the ozonolysis, $20 \%$ for the reaction with $\mathrm{OH}$ at low $\mathrm{NO}_{x}$, and $38 \%$ at high $\mathrm{NO}_{x}$ under dry conditions, $20^{\circ} \mathrm{C}$, and ozone excess. Parameterizations of the fresh SOA yields have been developed. The average fresh SOA atomic O:C ratio varied from 0.24 to 0.34 depending on the oxidant and the $\mathrm{NO}_{x}$ level, while the $\mathrm{H}: \mathrm{C}$ ratio was close to 1.5 for all systems examined. An average density of $1.06 \pm 0.1 \mu \mathrm{g} \mathrm{m}^{-3}$ of the $\beta$-caryophyllene SOA was estimated. The exposure to UV light had no effect on the $\beta$-caryophyllene SOA concentration and aerosol mass spectrometer (AMS) measurements. The chemical aging of the $\beta$-caryophyllene SOA produced was studied by exposing the fresh SOA to high concentrations $\left(10^{7}\right.$ molecules $\left.\mathrm{cm}^{-3}\right)$ of $\mathrm{OH}$ for several hours. These additional reactions increased the SOA concentration by $15-40 \%$ and $\mathrm{O}: \mathrm{C}$ by approximately $25 \%$. A limited number of experiments suggested that there was a significant impact of the relative humidity on the chemical aging of the SOA. The evaporation rates of $\beta$-caryophyllene SOA were quantified by using a thermodenuder allowing us to estimate the corresponding volatility distributions and effective vaporization enthalpies.
\end{abstract}

\section{Introduction}

Organic compounds represent approximately half of the total mass of sub-micrometer aerosol particles (Kanakidou et al., 2005). From a source perspective, organic aerosol (OA) is often classified as primary (POA) or secondary (SOA). POA refers to the organic mass that is emitted in the atmosphere in the particle phase. SOA is formed in the atmosphere when volatile organic compounds (VOCs) react with atmospheric oxidants such as ozone $\left(\mathrm{O}_{3}\right)$, hydroxyl radical $(\mathrm{OH})$, or nitrate radical $\left(\mathrm{NO}_{3}\right)$. These reactions form low-volatility products that can condense on preexisting particles in the atmosphere. Both POA and SOA have biogenic and anthropogenic sources.

The initial products of the oxidation of VOCs in the atmosphere can undergo subsequent reactions in the gas and particulate phases, leading to changes in their volatility and thus phase partitioning. This series of processes is called chemical aging and can be a significant source of SOA in the atmosphere (Donahue et al., 2012).

Biogenic VOCs, whose emissions exceed anthropogenic emissions on a global scale, play an important role in atmospheric chemistry at both regional and global scales (Kanakidou et al., 2005). Biogenic VOCs include monoterpenes $\left(\mathrm{C}_{10} \mathrm{H}_{16}\right)$, sesquiterpenes $\left(\mathrm{C}_{15} \mathrm{H}_{24}\right)$, and isoprene $\left(\mathrm{C}_{5} \mathrm{H}_{8}\right)$ as well as oxygenated compounds such as methanol, 2-methyl3-buten-2-ol, 6-methyl-5-hepten-2-one (Atkinson and Arey, 2003). Although isoprene and the monoterpenes have higher emission rates, the sesquiterpenes $\left(\mathrm{C}_{15} \mathrm{H}_{24}\right)$ are of special importance due to their high reactivity towards atmospheric 
oxidants and their large aerosol formation potential (Griffin et al., 1999b).

Sesquiterpenes are mostly emitted by conifers, deciduous trees, and flowers (Knudsen et al., 1993). $\beta$ Caryophyllene is often one of the most abundant sesquiterpenes (Helmig et al., 2007). It has two double bonds so its oxidation occurs in two steps. The reaction rate constants for the two reactions steps are $k_{1}=1.2 \pm 0.4 \times$ $10^{-14} \mathrm{~cm}^{3}$ molecule $\mathrm{e}^{-1} \mathrm{~s}^{-1}$ (Shu and Atkinson, 1995) and $k_{2}=1.1 \pm 0.4 \times 10^{-16} \mathrm{~cm}^{3}$ molecule ${ }^{-1} \mathrm{~s}^{-1}$ (Winterhalter et al., 2009), respectively. Assuming an $\mathrm{O}_{3}$ mixing ratio of $40 \mathrm{ppb}$, the atmospheric lifetime of $\beta$-caryophyllene is $1.5 \mathrm{~min}$ and the lifetime of the first-generation products is approximately $2.5 \mathrm{~h}$. The first- and second-generation oxidation products of $\beta$-caryophyllene that have been detected in the particle phase include $\beta$-caryophyllonic acid, $\beta$-caryophyllinic acid, $\beta$-caryophyllon aldehyde, and $\beta$ nocaryophyllon aldehyde (Jaoui et al., 2003; Winterhalter et al., 2009; $\mathrm{Li}$ et al., 2011). The ambient concentrations of most of these have not been quantified due to the lack of suitable standards. The lifetime of $\beta$-caryophyllene due to the reaction with $\mathrm{OH}$ radicals (assuming an $\mathrm{OH}$ concentration of $2 \times 10^{6}$ molecule $\mathrm{cm}^{-3}$ ) is approximately $40 \mathrm{~min}$ (Atkinson and Arey, 2003).

A number of earlier studies have measured the SOA yield of $\beta$-caryophyllene ozonolysis. The SOA yield increases with increasing OA levels as predicted by Odum et al. (1996). Winterhalter et al. (2009) reported SOA yields of 6 to $41 \%$ for $50-440 \mu \mathrm{g} \mathrm{m}^{-3}$ of SOA. Chen et al. (2012) found that the SOA yield is sensitive to the $\mathrm{O}_{3}$ concentration, especially for SOA levels higher than $10 \mu \mathrm{g} \mathrm{m}^{-3}$. They measured SOA yields of 8 to $46 \%$ for $0.5-170 \mu \mathrm{g} \mathrm{m}^{-3}$ of SOA for the reaction of $\beta$-caryophyllene with $50 \mathrm{ppb}$ of $\mathrm{O}_{3}, 15.8$ to $60 \%$ for $2.1-230 \mu \mathrm{g} \mathrm{m}^{-3}$ of SOA for $100 \mathrm{ppb}$ of $\mathrm{O}_{3}$, and 14.6 to

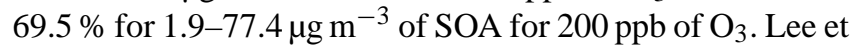
al. (2006a) (also reported in Ng et al., 2006) found a yield of $45 \%$ for $336 \mu \mathrm{g} \mathrm{m}^{-3}$ SOA while Jaoui et al. (2013) measured an SOA yield of $53 \%$ for $55.4 \mu \mathrm{g} \mathrm{m}^{-3}$ SOA. These results are quite inconsistent with relatively low values suggested by Winterhalter et al. (2009) and Lee et al. (2006a, b).

Oxidation of $\beta$-caryophyllene by $\mathrm{OH}$ radicals in the presence of light has also been studied. Lee et al. (2006b) produced $\mathrm{OH}$ radicals by the photolysis of HONO and measured an SOA yield of $68 \%$ for $212 \mu \mathrm{g} \mathrm{m}^{-3}$ SOA. Other studies investigated the photooxidation of $\beta$-caryophyllene- $\mathrm{NO}_{x}$ mixtures. Griffin et al. (1999a) found an SOA yield of 37$79 \%$ for $18-82 \mu \mathrm{g} \mathrm{m}^{-3}$ SOA while Hoffmann et al. (1997) found an SOA yield of $103-125 \%$ for $845-998 \mu \mathrm{g} \mathrm{m}^{-3}$, Alfarra et al. (2012) reported an SOA yield of $9.5-26.7 \%$ for 35.6-128.8 $\mu \mathrm{g} \mathrm{m}^{-3}$, and Jaoui et al. (2013) measured an SOA yield of $30 \%$ for $54 \mu \mathrm{g} \mathrm{m}^{-3}$ SOA. Jaoui et al. (2013) also reported an effective enthalpy of vaporization of $43.9 \mathrm{~kJ} \mathrm{~mol}^{-1}$ for aerosol generated from $\beta$-caryophyllene ozonolysis and $41.1 \mathrm{~kJ} \mathrm{~mol}^{-1}$ for aerosol generated from $\beta$-caryophyllene photooxidation. Finally, Chan et al. (2011) and Offenberg et al. (2009) found that the SOA yield during $\beta$-caryophyllene photooxidation is enhanced by aerosol acidity. Chan et al. (2011) showed that increased acidity leads to increased concentration of organosulfates and other particle-phase reaction products formed via hydration. This acidity effect has not been investigated in the current work.

There are significant discrepancies among the results of previous studies regarding the SOA yield in the system. Potential reasons for the differences include the absence, in some of the studies, of the correction of the mass of the particles that is lost on the walls of the smog chamber reactor. Other reasons include challenges with the injection and measurement of $\beta$-caryophyllene (Jaoui et al., 2013; Lee et al., 2006a; Helmig et al., 2004). Jaoui et al. (2013) did not use an $\mathrm{OH}$ scavenger, and therefore $\mathrm{OH}$ radicals were produced in their system, potentially leading the system to different reaction pathways. Winterhalter et al. (2009) did not use excess $\mathrm{O}_{3}$, while in some experiments Criegee intermediates scavengers were used. Winterhalter et al. (2009), Lee et al. (2006a, b), Alfarra et al. (2012) and Hoffmann et al. (1997) calculated the SOA assuming an effective density ranging from 1 to $1.3 \mu \mathrm{g} \mathrm{m}^{-3}$, depending on the study. Chen et al. (2012) estimated effective density values from 1.23 to $1.81 \mu \mathrm{g} \mathrm{m}^{-3}$ for their experiments. Relative humidity and temperature might also affect the yield. All the previous studies were conducted at temperatures of $20-26^{\circ} \mathrm{C}$, apart from Hoffmann et al. (1997), who used much higher temperatures ranging from 43 to $49^{\circ} \mathrm{C}$. Finally the relative humidity ranged from 5 to $72 \%$ in the studies, making the comparison of their results even more challenging.

The objective of this work is to measure the amount of aerosol produced by the reaction of $\beta$-caryophyllene with $\mathrm{O}_{3}$ or $\mathrm{OH}$ radicals and suggest aerosol yield parameterizations for atmospheric chemical transport models. We also examine the effect that UV light and temperature has on the $\beta$ caryophyllene SOA. The volatility and the effective vaporization enthalpy of $\beta$-caryophyllene SOA are estimated. Finally, the chemical aging of the SOA as it continues reacting with $\mathrm{OH}$ radicals is investigated.

\section{Experimental methods}

Experiments were carried out in the smog chamber of Carnegie Mellon University Center for Atmospheric Particle Studies (CAPS). The smog chamber is a $12 \mathrm{~m}^{3}$ Teflon reactor (Welch Fluorocarbons). The chamber was suspended inside a temperature-controlled room. The walls of the smog chamber room were lined with UV lights (General Electric, model 10526 black). Prior to an experiment, the chamber was flushed with purified air for $12-48 \mathrm{~h}$. Air was purified by passing through HEPA and carbon filters to remove particles and gas-phase organics, respectively, and through silica gel to reduce relative humidity to $<10 \%$. 
Ozone was added to the chamber using an electrical discharge generator (AZCO, model HTU-500ACPS). In addition, $0.5 \mathrm{~mL}$ of 2-butanol (Sigma-Aldrich, ReagentPlus, $\geq 99 \%$ ) was introduced into the chamber as an $\mathrm{OH}$ scavenger before selected experiments to avoid the oxidation of the precursor by the $\mathrm{OH}$ produced during the ozonolysis experiments. We tested the possibility of the formation of aerosol from the reaction of $\mathrm{OH}$ and 2-butanol in the presence of ammonium sulfate seeds. There was no detectable organic aerosol formation for the conditions used in our experiments. For the photooxidation experiments, we used HONO and $\mathrm{H}_{2} \mathrm{O}_{2}$ (Sigma-Aldrich, 50-50\% solution) photolysis as the source of $\mathrm{OH}$ radicals. A fresh solution of HONO was produced and used in each experiment. HONO was produced by mixing a $4.9 \mathrm{~g} \mathrm{~L}^{-1}$ sulfuric acid solution with a $6.9 \mathrm{~g} \mathrm{~L}^{-1}$ sodium nitrite solution with a volumetric ratio of $2: 1$. $\mathrm{HONO}$ or $\mathrm{H}_{2} \mathrm{O}_{2}$ were injected into the chamber using a bubbler. After the injection, the UV lights were turned on to initiate the production of $\mathrm{OH}$ radicals. We tested the injection method by measuring the concentration of the $\mathrm{OH}$ radicals using 2-butanol as a tracer and a GC/FID (Chromatotec airmoBTX) with a 15 min time resolution. The estimated concentration of $\mathrm{OH}$ radicals was approximately $10^{7}$ molecules $\mathrm{cm}^{-3}$ for HONO photolysis and $10^{6}$ molecules $\mathrm{cm}^{-3}$ for $\mathrm{H}_{2} \mathrm{O}_{2}$ photolysis. We did not add any $\mathrm{NO}_{x}$ to the chamber for the ozonolysis experiments and the low- $\mathrm{NO}_{x}$ experiments. The measured $\mathrm{NO}_{x}$ level was of the order of a few parts per billion for these experiments. For the high- $\mathrm{NO}_{x}$ experiments, the corresponding $\mathrm{NO}_{x}$ concentrations, due to the dissociation of HONO, were more than 1 ppm.

$\beta$-Caryophyllene (Sigma-Aldrich, $\geq 98.5 \%$ ) was injected through a heated septum injector in which clean air was passed over the injected liquid to vaporize and transfer it to the chamber via Teflon tubing. The concentration of the $\beta$-caryophyllene that reacted in the chamber was calculated based on injected mass. Previous studies have reported tubing losses during the injection of "sticky" compounds such as sesquiterpenes (Jaoui et al., 2013; Lee et al., 2006a; Helmig et al., 2004). To overcome this problem, we tested the injection by gently purging the Teflon tubing with clean air $\left(5 \mathrm{~L} \mathrm{~min}^{-1}\right)$ for $1 \mathrm{~h}$ after the injection. The signal of $m / z 81$ of a proton-transfer reactor mass spectrometer (PTR-MS, Ionicon Analytic $\mathrm{GmbH}$ ), which has been found to be a strong signal for $\beta$-caryophyllene (Lee et al., 2006a, b), was measured. During the tests the initial signal of $m / z 81$ was 0 and after the injection and the purging of the line the signal increased and reached a plateau. We found that 10-20 min of purging was sufficient for the complete $\beta$-caryophyllene injection into the chamber. The accuracy of the estimated concentration based on the injected $\beta$-caryophyllene amount was checked in selected experiments using the PTR-MS. The total amount of air added to the chamber during the purging was less than $0.3 \mathrm{~m}^{-3}$ (less than $3 \%$ of the chamber volume)
A scanning mobility particle sizer (SMPS, TSI classifier model 3080, CPC model 3772 or 3010) was used for the measurement of the number and the volume distributions of aerosols. The mass concentration and the chemical composition of the particles were monitored using a highresolution time-of-flight aerosol mass spectrometer (HRToF-AMS, Aerodyne Research, Inc.). For the HR-ToF-AMS data analysis, SQUIRREL 1.51H (SeQUential Igor data RetRiEvaL) and PIKA $1.10 \mathrm{H}$ (Peak Intergration by Key Analysis) were used. In our analysis we used the fragmentation table of Aiken et al. (2008). The HR-ToF-AMS was operated alternatively between $\mathrm{V}$-mode and $\mathrm{W}$-mode with $1 \mathrm{~min}$ of measurement time for each mode. In this paper the Vmode data are presented. The elemental ratios of the SOA were calculated using the HR-ToF-AMS data without including the organonitrate fragments in the analysis (Farmer et al., 2010). The concentration of $\mathrm{O}_{3}$ was measured using a continuous $\mathrm{O}_{3}$ analyzer (Dasibi 1008-PC), and the concentration of nitrogen oxides was measured using a Teledyne chemiluminescence $\mathrm{NO} / \mathrm{NO}_{2} / \mathrm{NO}_{x}$ analyzer (Model 200A).

The reported SOA mass concentration was calculated by using the volume distribution and the density of the $\beta$ caryophyllene SOA. In each experiment we used the algorithm of Kostenidou et al. (2007) to estimate the effective density of the SOA and the collection efficiency (CE) of the HR-ToF-AMS. This algorithm combines the volume and mass distributions of the aerosol measured, respectively, by the SMPS and HR-ToF-AMS.

A major complication in smog chamber experiments is that particles, and potentially vapors, are lost to the walls of the reactor. As a result the number and the mass concentration of the particles decrease continuously. The particle wall loss rate in general depends on particle size, the geometry of the smog chamber, the turbulence and electric fields within the chamber, and the charge distribution of the particles (Crump and Seinfeld, 1981). A semiempirical approach for calculating the particle wall losses (Pathak et al., 2007) involves measuring an average mass wall loss rate constant in the chamber after the reactions are completed and then applying this constant to the entire experiment. This method assumes that the wall loss rate is first order and independent of particle size for the particle size range in the chamber. To ensure that the rate constants were estimated during periods in which the reactions rate was very low or 0 , we used three different criteria. The first was the theoretical estimates of the reaction times. For example in all the ozonolysis experiments in which the $\mathrm{O}_{3}$ concentration was in excess of $300 \mathrm{ppb}$, the time required for the first reaction step at $293 \mathrm{~K}$ is approximately $12 \mathrm{~s}$ while the second requires around $20 \mathrm{~min}$. To ensure that these reactions were completed, the particle wall loss rate constants were estimated by using the mass concentration decay at least after 1 hour from the beginning of the reactions. The second criterion was the testing of subperiods after the reaction completion to ensure that there was no change in the corresponding constant from period to period. 
For example in Experiment 6 (Table 1) we calculated a wall loss rate constant of $0.29 \mathrm{~h}^{-1}$ for the $50-100 \mathrm{~min}$ period (with $R^{2}=0.98$ ), of $0.29 \mathrm{~h}^{-1}$ for $100-150 \mathrm{~min}$ (with $R^{2}=0.99$ ), and of $0.28 \mathrm{~h}^{-1}$ for $150-200 \mathrm{~min}$ (with $R^{2}=0.99$ ). Similar results were obtained for other experiments during periods in which the reactions in the system were assumed to be completed. The third criterion was the use of periods in which the SOA O:C ratio was stable. The wall loss rate constants at $293 \mathrm{~K}$ estimated for all the ozonolysis experiment were equal to $0.27 \pm 0.13 \mathrm{~h}^{-1}$.

The use of a time-independent value for the correction of the wall losses (even if sub- $100 \mathrm{~nm}$ particles are, in general, lost more quickly than larger particles in our system) is justified by the fact that particles in our experiments grew to sizes above $100 \mathrm{~nm}$ in less than $20 \mathrm{~min}$. Therefore, the period during which losses may have been different was small and the resulting uncertainty was also small. We estimate that the uncertainty in the yields introduced by the particle wall loss correction is of the order of $20 \%$ for this fast-reacting system.

Changes in temperature do result in significant changes in the loss rate constants in our chamber. In Experiment 1, in which the temperature was increased from 20 to $40^{\circ} \mathrm{C}$, the particle loss rate constant increased from 0.26 to $0.46 \mathrm{~h}^{-1}$. This increase is due to the increased ventilation outside the chamber, which leads to increased turbulence inside the chamber and thus increased particle losses. We have estimated and used different loss rate constants for periods with different temperatures in the same experiment.

Most previous studies have neglected the losses of organic vapors on the particles deposited on the reactor walls. Hildebrandt et al. (2011) developed a method that calculates SOA yields in two extreme cases: when there are no vapor losses on the particles deposited on the walls $(w=0)$, similar to Pathak et al. (2007), and when organic vapors condense on the particles on the walls in a way similar to the suspended particles in the reactor $(w=1)$. We have corrected for vapor losses to the particles deposited on the chamber walls using both the $w=0$ and the $w=1$ approaches (Table 1).

Matsunaga and Ziemann (2010) and Zhang et al. (2014) have also reported the loss of organic vapors directly onto the Teflon walls. The measurement of these losses during SOA formation is challenging. To quantify the magnitude of these losses, we have performed four additional experiments using ammonium sulfate seeds. The use of the seeds increases the surface area of the aerosol in the chamber and should reduce any artifact related to vapor losses to the Teflon wall. The results of these experiments are discussed in Sect. 3.1.

The oxidation of $\beta$-caryophyllene took place at a constant temperature of $20 \pm 2{ }^{\circ} \mathrm{C}$ and at $\mathrm{RH}<10 \%$ in most experiments. Two experiments were conducted at higher relative humidity, equal to 50 and $90 \%$. No high-RH experiments were conducted in the presence of ammonium sulfate particles. The interactions of aerosol water, inorganic ions, and
Table 1. Initial conditions and results of the $\beta$-caryophyllene oxidation experiments.

\begin{tabular}{|c|c|c|c|c|c|c|c|}
\hline \multirow[t]{2}{*}{ Exp } & \multirow[t]{2}{*}{$\begin{array}{r}\text { VOC } \\
(\mathrm{ppb})^{\mathrm{a}}\end{array}$} & \multirow[t]{2}{*}{$\begin{array}{r}\mathrm{O}_{3} \\
(\mathrm{ppb})\end{array}$} & \multirow[t]{2}{*}{$\begin{array}{r}\text { Seeds } \\
\left(\mu \mathrm{g} \mathrm{m}^{-3}\right)\end{array}$} & \multirow[t]{2}{*}{$\begin{array}{r}\text { SOA } \\
\text { density } \\
\left(\mathrm{g} \mathrm{cm}^{-3}\right)\end{array}$} & \multicolumn{2}{|c|}{$\begin{array}{l}\text { SOA mass } \\
\left(\mu \mathrm{g} \mathrm{m}^{-3}\right)^{\mathrm{b}}\end{array}$} & \multirow[t]{2}{*}{$\begin{array}{l}\text { SOA } \\
\text { yield } \\
(\%)^{\mathrm{c}}\end{array}$} \\
\hline & & & & & $w=0$ & $w=1$ & \\
\hline \multicolumn{8}{|c|}{ Ozonolysis (in the presence of $\mathrm{OH}$ scavenger) } \\
\hline 1 & 13 & 300 & - & 1.01 & 41.2 & 45 & 41.7 \\
\hline 2 & 14 & 300 & - & 0.97 & 47.6 & 50.7 & 43.3 \\
\hline 3 & 5 & 600 & - & 0.93 & 10.9 & 11 & 24.2 \\
\hline 4 & 32 & 300 & - & 0.97 & 89.2 & 95.1 & 34.8 \\
\hline 5 & 2 & 600 & - & 0.97 & 0.3 & 0.3 & 1.9 \\
\hline 6 & 4 & 300 & - & 0.95 & 8.9 & 9.4 & 29.4 \\
\hline 7 & 21 & 300 & - & 0.98 & 108 & 119 & 65.2 \\
\hline 8 & 11 & 300 & - & 0.96 & 44.8 & 52 & 57.1 \\
\hline 9 & 27 & 300 & - & 0.95 & 88.6 & 97.7 & 42.8 \\
\hline 10 & 19 & 300 & - & 1.03 & 84.6 & 96.2 & 58.6 \\
\hline 11 & 30 & 300 & - & 0.96 & 140 & 163 & 63.7 \\
\hline 12 & 13 & 300 & - & 0.96 & 56 & 65.4 & 59.7 \\
\hline 13 & 24 & 300 & - & 0.99 & 162 & 194 & 96.1 \\
\hline 14 & 3 & 300 & - & 0.99 & 12.4 & 13.2 & 48.2 \\
\hline 15 & 23 & 300 & 26.7 & 1.17 & 108.3 & 113.2 & 59.1 \\
\hline 16 & 25 & 300 & 53 & 1.00 & 175.9 & 180.6 & 86.1 \\
\hline 17 & 16 & 300 & 30.1 & 1.01 & 113.5 & 119 & 86.9 \\
\hline 18 & 11 & 300 & 22.3 & 1.02 & 89.5 & 94.4 & 103.4 \\
\hline \multicolumn{8}{|c|}{$\mathrm{OH}$ radicals at high $\mathrm{NO}_{x}$} \\
\hline 19 & 11 & - & - & 1.12 & 78.1 & 81.2 & 89 \\
\hline 20 & 24 & - & - & 1.25 & 223 & 229 & 113.9 \\
\hline 21 & 32 & - & - & 1.21 & 303 & 311 & 113.5 \\
\hline 22 & 5 & - & - & 1.12 & 43.2 & 44.4 & 97.4 \\
\hline 23 & 3 & - & - & 1.06 & 7.8 & 8.4 & 30.7 \\
\hline 24 & 4 & - & - & 1.34 & 20.1 & 20.1 & 55.2 \\
\hline 25 & 19 & - & - & 1.22 & 222.1 & 226.3 & 137.8 \\
\hline \multicolumn{8}{|c|}{ OH radicals at low $\mathrm{NO}_{x}$} \\
\hline 26 & 32 & - & - & 1.02 & 156 & 193 & 70.3 \\
\hline 27 & 16 & - & - & 1.08 & 55.7 & 56.9 & 41.6 \\
\hline 28 & 11 & - & - & 1.07 & 47.2 & 49.0 & 53.7 \\
\hline 29 & 5 & - & - & 0.99 & 8 & 8.8 & 19.3 \\
\hline 30 & 21 & - & - & 1.09 & 97.8 & 97.7 & 53.5 \\
\hline
\end{tabular}

a This concentration is calculated based on the amount of $\beta$-caryophyllene injected into the chamber-

${ }^{\mathrm{b}}$ Wall-loss-corrected mass concentration measured by the SMPS using the corresponding density.

${ }^{c}$ The SOA yields are calculated using the wall-loss-corrected SOA mass concentration for $w=1$.

the SOA compounds in this system require additional detailed studies.

After the reactions were completed, the chamber was heated to $40^{\circ} \mathrm{C}$ to investigate the evaporation of the particles produced. For the investigation of the behavior of the SOA at higher temperatures we used the thermodenuder of An et al. (2007). The temperatures in the thermodenuder were in the range of $25-120^{\circ} \mathrm{C}$, with a centerline residence time of $26 \mathrm{~s}$. Tables 1 and 2 list the initial conditions and the calculated SOA yields for all experiments. 


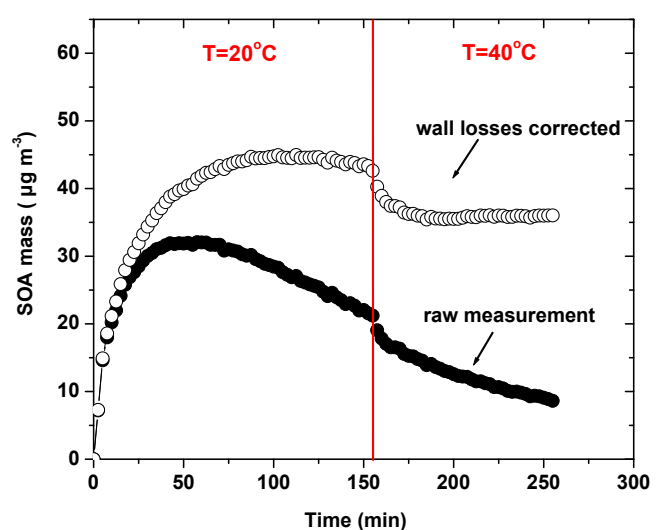

Figure 1. The measured aerosol mass concentration in the chamber as a function of time and the wall-loss-corrected SOA mass concentration (for $w=1$ ) for Experiment 1. Also shown is the time when the temperature inside the chamber was increased.

\section{Results and discussion}

\subsection{Ozonolysis}

The results of a typical ozonolysis experiment (Experiment 1) are shown in Fig. 1. Initially, we injected 2-butanol and $\mathrm{O}_{3}$ into the chamber, followed by the injection of $\beta$ caryophyllene. The reaction started at time 0 with the presence of both reactants in the smog chamber. The mass of the aerosol started increasing right away, and $30 \mathrm{~min}$ later the SOA concentration reached $32 \mu \mathrm{g} \mathrm{m}^{-3}$. The temperature was increased to $40^{\circ} \mathrm{C} 2.5 \mathrm{~h}$ after the beginning of the experiment. Approximately $6 \mu \mathrm{g} \mathrm{m}^{-3}$ of suspended SOA evaporated in $20 \mathrm{~min}$ (Fig. 1). The wall-loss-corrected SOA mass decreased by $15 \%$ due to evaporation. After 20 min the system appeared to reach equilibrium and the suspended mass decreased again slowly due to wall losses.

In Experiment 2 (not shown) the $\beta$-caryophyllene SOA produced in the dark during ozonolysis was exposed to UVlight. The SOA formed had a wall-loss-corrected mass of $50.7 \mu \mathrm{g} \mathrm{m}^{-3}$ and $\mathrm{O}: \mathrm{C}$ of 0.38 . Approximately $1.5 \mathrm{~h}$ after the mass of the SOA started decreasing in the smog chamber, we turned on the UV lights. After 1 hour of exposure the wallloss-corrected SOA concentration was $50.1 \mu \mathrm{g} \mathrm{m}^{-3}$ and the $\mathrm{O}: \mathrm{C}$ was 0.38 . We compared the mass spectra in these two periods using the angle $\theta$ between the corresponding vectors as described in Kostenidou et al. (2009). The $\theta$ angle was less than $2^{\circ}$, suggesting that there were no noticeable effects of chemical aging or photolysis of the SOA, at least from the point of view of the AMS.

The wall-loss-corrected aerosol mass concentrations are presented in Table 1 for two extreme cases: for the case which assumes that there are no vapor losses to the particles deposited on the walls $(w=0)$ and for the case in which organic vapors condense on the particles on the walls in a way similar to the suspended particles in the reactor $(w=1)$

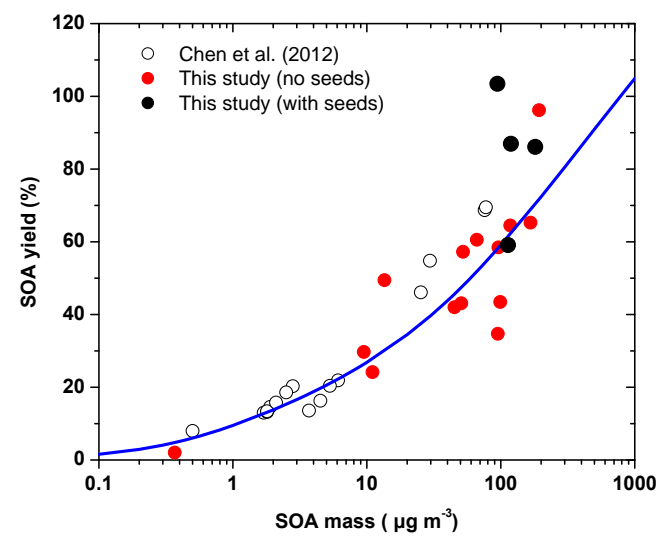

Figure 2. The SOA yield versus the total mass produced (for $w=$ 1). The red dots are the results of this study from the unseeded experiments, and the black dots are results from the experiments in which ammonium sulfate seeds were used. The open symbols are the results of Chen et al. (2012). The solid line is the fitting of the data from both studies using the volatility basis set (VBS) framework.

(Hildebrandt et al., 2011). Because reactions are fast in this system, the $w=1$ case results are at most $20 \%$ higher than that the $w=0$ ones. In Experiments 15-18 we used ammonium sulfate seeds to test for direct losses of vapors to the Teflon wall. The yields of these experiments (Fig. 2) are not different from the rest of the yields. This suggests that the magnitude of losses of vapors to the walls for this fastreacting system is of the same order as the variability of the yields calculated in the rest of the experiments, with artifacts of the order of $20-30 \%$.

The average density of the SOA formed in the ozonolysis experiments was $0.99 \pm 0.05 \mu \mathrm{g} \mathrm{m}^{-3}$ (Table 1), a value lower than the values calculated by Chen et al. (2012). The approaches that were used for the density estimation are different; we matched the full distributions, while Chen et al. (2012) relied on the mass mode diameters. The variation of composition with size (seeds were used in the Chen et al., 2012, and there could be more organics condensing on the smaller and less on the larger particles) could introduce some additional uncertainty in approaches that use one particle size and the average particle composition.

For the ozonolysis experiments under dry conditions $(\mathrm{RH}=1-5 \%)$, the corresponding average HR-ToF-AMS collection efficiency was $\mathrm{CE}=0.59 \pm 0.12$. Docherty et al. (2013) reported an even lower AMS CE of $0.36 \pm 0.01$ for $\beta$-caryophyllene ozonolysis SOA under dry conditions, while Chen et al. (2012) found $\mathrm{CE}=1$ for moderate relative humidity ( $\mathrm{RH}=40 \pm 1 \%$ ) experiments. The $\mathrm{CE}$ in our higher-RH experiments described later (Experiments 34 and 35 ) was around 0.5 , similar to the experiments under dry conditions. The CE differences between our study and Chen et al. (2012) are probably due to AMS instrument differences. 
Table 2. Initial conditions and results of the aging experiments.

\begin{tabular}{|c|c|c|c|c|c|c|c|c|c|c|c|c|c|c|}
\hline \multirow{3}{*}{ Exp } & \multirow{3}{*}{$\begin{array}{r}\text { VOC } \\
(\mathrm{ppb})^{\mathrm{a}}\end{array}$} & \multirow{3}{*}{$\begin{array}{r}\mathrm{O}_{3} \\
(\mathrm{ppb})\end{array}$} & \multirow{3}{*}{$\begin{array}{l}\mathrm{RH} \\
(\%)\end{array}$} & \multirow{3}{*}{$\begin{array}{r}\text { SOA } \\
\text { density } \\
\left(\mathrm{g} \mathrm{cm}^{-3}\right)\end{array}$} & \multicolumn{5}{|c|}{ Fresh SOA } & \multicolumn{5}{|c|}{ Aged SOA } \\
\hline & & & & & \multicolumn{2}{|c|}{$\begin{array}{l}\text { SOA mass } \\
\left(\mu \mathrm{g} \mathrm{m}^{-3}\right)^{\mathrm{b}}\end{array}$} & \multirow[t]{2}{*}{$\mathrm{O}: \mathrm{C}$} & \multirow[t]{2}{*}{$\mathrm{H}: \mathrm{C}$} & \multirow[t]{2}{*}{$\begin{array}{l}\text { SOA } \\
\text { yield } \\
(\%)^{\mathrm{c}}\end{array}$} & \multicolumn{2}{|c|}{$\begin{array}{l}\text { SOA mass } \\
\left(\mu \mathrm{g} \mathrm{m}^{-3}\right)^{\mathrm{b}}\end{array}$} & \multirow[t]{2}{*}{$\mathrm{O}: \mathrm{C}$} & \multirow[t]{2}{*}{$\mathrm{H}: \mathrm{C}$} & \multirow[t]{2}{*}{$\begin{array}{l}\text { SOA } \\
\text { yield } \\
(\%)^{\mathrm{c}}\end{array}$} \\
\hline & & & & & $w=0$ & $w=1$ & & & & $w=0$ & $w=1$ & & & \\
\hline 31 & 3 & 300 & $<10$ & 1.12 & 17 & 17.6 & 0.26 & 1.48 & 64.4 & 18.6 & 20.6 & 0.32 & 1.48 & 75.4 \\
\hline 34 & 3 & 300 & $\sim 50$ & 1.15 & 32.8 & 33.7 & 0.28 & 1.43 & 123.3 & 44 & 47.2 & 0.35 & 1.43 & 140 \\
\hline 35 & 3 & 300 & $\sim 90$ & 1.21 & 22.7 & 23 & 0.21 & 1.47 & 84.2 & 29.4 & 32.1 & 0.28 & 1.45 & 117.5 \\
\hline 36 & 5 & 500 & $<10$ & 1.00 & 28.6 & 30.5 & 0.28 & 1.44 & 66.9 & 28.8 & 30.8 & 0.29 & 1.44 & 67.6 \\
\hline 37 & 3 & 400 & $<10$ & 1.13 & 16 & 16.3 & 0.31 & 1.46 & 59.6 & 16.2 & 16.7 & 0.31 & 1.46 & 61.1 \\
\hline
\end{tabular}

a This concentration was calculated based on the amount of $\beta$-caryophyllene injected into the chamber.

$\mathrm{b}$ This is the wall-loss-corrected mass concentration measured by the SMPS.

${ }^{\mathrm{c}}$ The SOA yields are calculated using the wall-loss-corrected SOA mass concentration for $w=1$.

The average $\mathrm{O}: \mathrm{C}$ ratio of the fresh SOA produced was $0.31 \pm 0.04$, and the $\mathrm{H}: \mathrm{C}$ ratio was $1.5 \pm 0.03$. There was no difference in the elemental ratios between the seeded and unseeded experiments. Chen et al. (2012) reported higher O : C values ranging from 0.33 to 0.54 . The difference in $\mathrm{O}: \mathrm{C}$ between this study and Chen et al. (2012) is partially due to the use of the Aiken et al. (2008) fragmentation table in our study, while the approach of Chen et al. (2011) was used by Chen et al. (2012). To investigate the sensitivity of our estimated $\mathrm{O}: \mathrm{C}$ to the algorithm used for its calculation, we also used the Canagaratna et al. (2015) O:C estimation approach for two of our experiments. For Experiment 6 we estimated $\mathrm{O}: \mathrm{C}=0.25$ and $\mathrm{H}: \mathrm{C}=1.45$, and after the correction we obtained $\mathrm{O}: \mathrm{C}=0.44$ and $\mathrm{H}: \mathrm{C}=1.69$. For Experiment 12 we estimated $\mathrm{O}: \mathrm{C}=0.35$ and $\mathrm{H}: \mathrm{C}=1.49$, and after the correction we obtained $\mathrm{O}: \mathrm{C}=0.53$ and $\mathrm{H}: \mathrm{C}=1.7$. These results do underline the sensitivity of the $\mathrm{O}: \mathrm{C}$ ratio to the specifics of the fragmentation table used for its calculation.

The SOA yields for the ozonolysis experiments were similar to the "ultimate yields" (no data above $10 \mu \mathrm{g} \mathrm{m}^{-3}$ and $\mathrm{O}_{3}$ concentration less than $200 \mathrm{ppb}$ ) reported by Chen et al. (2012) (Fig. 2). Given that all our experiments covered periods much longer than the reaction timescales, potentially incomplete reactions cannot explain the observed scatter in the yields. We performed a few experiments at higher $\mathrm{RH}$, and the yields did not appear to be substantially different from the low-RH experiments (described later). Finally, the small temperature difference between our experiments and those of Chen et al. (2012) can only explain a few percent of the yield difference. Uncertainties in losses of vapors and particles and the reacted VOC are probably responsible for most of the scatter in Fig. 2. The dashed line in Fig. 2 represents the fitting of the data from the two studies using the volatility basis set framework (Donahue et al., 2006). The resulting parameters (mass yields
Table 3. Product mass yields for the three different reactions using a four-product volatility basis set.

\begin{tabular}{lrrrr}
\hline & \multicolumn{4}{c}{$\begin{array}{c}\text { Saturation concentration } \\
\left(\mu \mathrm{g} \mathrm{m}^{-3}\right)\end{array}$} \\
\cline { 2 - 5 } Reaction & 1 & 10 & 100 & 1000 \\
\hline Ozonolysis & 0.15 & 0.17 & 0.47 & 0.61 \\
OH radicals at high $\mathrm{NO}_{x}$ & 0.01 & 0.59 & 0.79 & 0.01 \\
OH radicals at low $\mathrm{NO}_{x}$ & 0.1 & 0.11 & 0.57 & 0.62 \\
\hline
\end{tabular}

of the products of the various volatilities) are shown in Table 3. This fitting suggests that $15 \%$ of the SOA had relatively low volatility $\left(\mathrm{C}^{*}=1 \mu \mathrm{g} \mathrm{m}^{-3}\right)$. For comparison, the mass yields for the ozonolysis products of sesquiterpenes that have been used in CTMs (chemical transport models) (Lane et al., 2008) for $\mathrm{C}^{*}=\{1,10,100,1000\} \mu \mathrm{g} \mathrm{m}^{-3}$ are $\alpha_{1}=0.05, \alpha_{2}=0.1, \alpha_{3}=0.5, \alpha_{4}=0.6$, respectively. This parameterization is a fit of the experimental studies of Griffin et al. (1999a), Hoffmann et al. (1997), and $\mathrm{Ng}$ et al. (2006). Chen et al. (2012) reported mass-based stoichiometric yields of $\alpha_{1}=0.17, \alpha_{2}=0.11$, and $\alpha_{3}=1.03$ for corresponding saturation concentrations of 1,10 , and $100 \mu \mathrm{g} \mathrm{m}^{-3}$. These results suggest that practically all the products of the $\beta$ caryophyllene ozonolysis have effective saturation concentrations less or equal than $1000 \mu \mathrm{g} \mathrm{m}^{-3}$.

\subsection{Oxidation via $\mathrm{OH}$}

In a second series of experiments, $\beta$-caryophyllene was oxidized by $\mathrm{OH}$ radicals produced by $\mathrm{HONO}$ photolysis. $\mathrm{NO}$ and $\mathrm{NO}_{2}$ were formed when $\mathrm{HONO}$ was injected into the chamber. Thus, in these experiments the oxidation happened under high- $\mathrm{NO}_{x}$ conditions

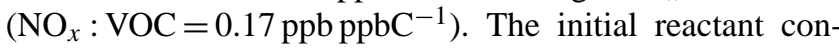




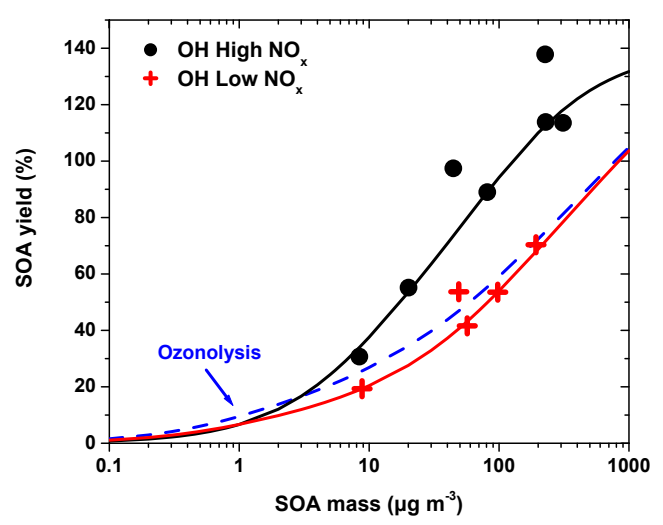

Figure 3. The SOA yield versus the total aerosol mass produced. The red dots represent the experiments when photolysis of HONO was used as a source of hydroxyl radicals, and the black dots are for the photolysis of $\mathrm{H}_{2} \mathrm{O}_{2}$. The dashed line corresponds to the SOA yield from the ozonolysis of $\beta$-caryophyllene.

centrations and the results of these experiments are listed in Table 1 . The average density of the SOA formed in these experiments was $1.19 \pm 0.1 \mathrm{\mu g} \mathrm{m}^{-3}$. The average collection efficiency of the HR-ToF-AMS was $0.38 \pm 0.11$. Figure 3 depicts the measured SOA yields as a function of SOA mass concentration. The SOA yields in these experiments were higher than the yields of ozonolysis experiments. The average $\mathrm{O}: \mathrm{C}$ ratio was $0.34 \pm 0.07$, and the $\mathrm{H}: \mathrm{C}$ ratio was $1.5 \pm 0.07$. The elemental ratios of the SOA were calculated using the HR-ToF-AMS without including the organonitrates. The $\mathrm{O}_{3}$ produced during the oxidation was always less than $10 \mathrm{ppb}$.

Similar experiments were performed using $\mathrm{OH}$ radicals produced by $\mathrm{H}_{2} \mathrm{O}_{2}$ photolysis. The SOA yields for these experiments were similar to the yields of $\beta$-caryophyllene ozonolysis (Table 1). The average density of the SOA formed in these series of experiments was $1.05 \pm 0.04 \mathrm{~g} \mathrm{~m}^{-3}$. The average $\mathrm{O}: \mathrm{C}$ ratio was $0.24 \pm 0.02$, and the $\mathrm{H}: \mathrm{C}$ ratio was $1.52 \pm 0.03$. The average collection efficiency of the HRToF-AMS was $0.67 \pm 0.1$. The SOA yields at low- $\mathrm{NO}_{x}$ conditions were lower than the ones at high- $\mathrm{NO}_{x}$ conditions. These results are consistent with $\mathrm{Ng}$ et al. (2007), who found that SOA yield increases with increasing $\mathrm{NO}_{x}$ levels during the formation of SOA from sesquiterpenes (longifolene and aromadendrene) oxidation by $\mathrm{OH}$. These authors suggested that the formation of low-volatility organonitrates might be one reason for the higher SOA yields. Before the reaction started, the HR-ToF-AMS nitrate signal was 0. After SOA formation, the ratio of the nitrate to the organic signal was $0.15 \pm 0.04$ in the high- $\mathrm{NO}_{x}$ experiments, while for the low$\mathrm{NO}_{x}$ experiments it was less than 0.01 . Another potential reason for the difference in the SOA yield is the concentration of the oxidant. HONO photolysis produced 1 order of magnitude higher levels of $\mathrm{OH}$ than $\mathrm{H}_{2} \mathrm{O}_{2}$ photolysis. We estimate that the exposure of the organics to $\mathrm{OH}$ was 10 times higher

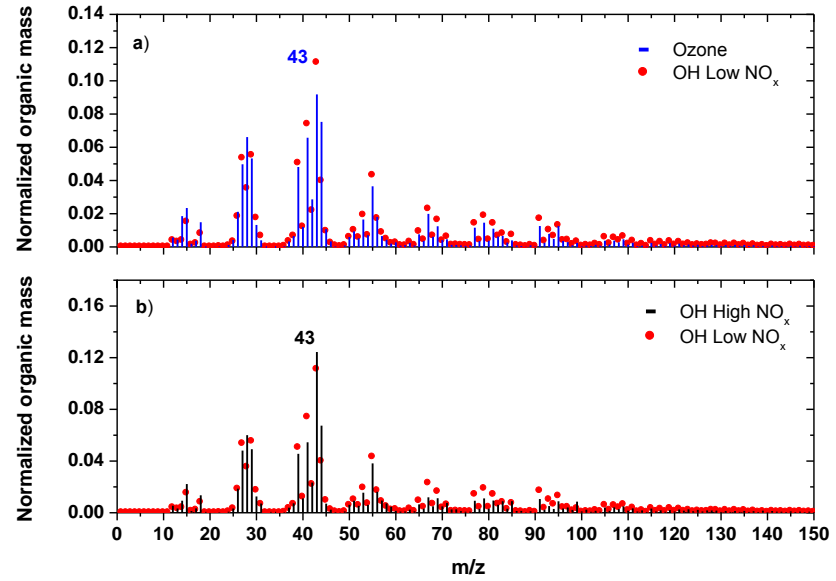

Figure 4. Comparison of the organic mass spectra of the $\beta$ caryophyllene SOA produced from the three reaction systems: (a) from ozonolysis and $\mathrm{OH}$ at low $\mathrm{NO}_{x}\left(\theta=12^{\circ}\right)$ and (b) from $\mathrm{OH}$ at high and low $\mathrm{NO}_{x}\left(\theta=15^{\circ}\right)$.

in the $\mathrm{HONO}$ experiments compared to the $\mathrm{H}_{2} \mathrm{O}_{2}$ ones for the period until the maximum yield was achieved. The existence of nitrated organosulfates can also affect the SOA yield (Chan et al., 2011). The $\mathrm{O}_{3}$ formed in these experiments was a few parts per billion, so its contribution to the SOA formed was small. This is consistent with the differences in the AMS spectra of the SOA formed during the ozonolysis and the $\mathrm{OH}$ experiments.

Our results suggest that there are substantial differences in $\beta$-caryophyllene SOA produced under different $\mathrm{NO}_{x}$ conditions. The density of the $\mathrm{SOA}$ produced under high- $\mathrm{NO}_{x}$ conditions is approximately $20 \%$ higher than that produced under low- $\mathrm{NO}_{x}$ conditions. Furthermore, during the oxidation of $\beta$-caryophyllene under high- $\mathrm{NO}_{x}$ conditions less volatile compounds are produced (Table 3). In Fig. 4 we compare the average mass spectra of the $\beta$-caryophyllene SOA produced by ozonolysis and reaction with $\mathrm{OH}$ at high $\mathrm{NO}_{x}$ and low $\mathrm{NO}_{x}$. The ozonolysis SOA spectra had significant differences from those produced by the $\mathrm{OH}$ reaction (lower $f_{43}$, higher $m / z f_{44}$, etc.) and $\theta$ angles of $12^{\circ}$ with the high- $\mathrm{NO}_{x}$ SOA and $17.1^{\circ}$ for the low-NO $\mathrm{NO}_{x}$ case. For the high- and low$\mathrm{NO}_{x}$ spectra (without accounting for the nitrate), the $\theta$ angle was $15^{\circ}$.

\subsection{Chemical aging of fresh $\beta$-caryophyllene SOA}

In another series of experiments, we studied the chemical aging of the $\beta$-caryophyllene SOA produced in this first set of reactions. The SOA in these experiments was produced by the oxidation of the $\beta$-caryophyllene with $\mathrm{O}_{3}$ in the presence of $\mathrm{OH}$ radicals (without the addition of $\mathrm{OH}$ scavenger). The SOA yield of this reaction is higher than the yields of the reactions of $\beta$-caryophyllene with the individual oxidants. The reason is probably the synergism between the two oxidants 


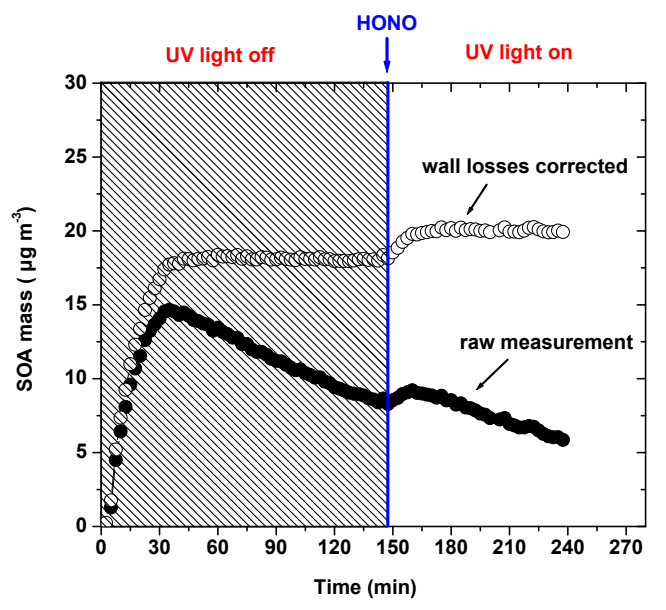

Figure 5. The measured aerosol mass concentration in the chamber as a function of time and the wall-loss-corrected SOA mass concentration (for $w=1$ ) (Experiment 31). The shaded part indicates the period when the UV light was off, and the other section represents the period when the UV light was on. Also shown is the time when HONO was injected into the chamber.

reacting with the first-generation products of the oxidation of $\beta$-caryophyllene. In experiments 31-37 (Table 2), we investigated the effect of the subsequent exposure to $\mathrm{OH}$ radicals on $\beta$-caryophyllene SOA. In experiments $31-35$ the $\mathrm{OH}$ radicals were produced by HONO photolysis, while in experiments 36 and 37 they were produced by $\mathrm{H}_{2} \mathrm{O}_{2}$ photolysis. The SOA mass concentration time series of Experiment 31 is presented in Fig. 5. SOA was formed by the reaction of $300 \mathrm{ppb}$ of $\mathrm{O}_{3}$ and $3 \mathrm{ppb}$ of $\beta$-caryophyllene. Approximately $1.5 \mathrm{~h}$ after the mass of the SOA started decreasing in the smog chamber, HONO was injected into the chamber and the UV lights were turned on resulting in the production of significant levels of $\mathrm{OH}$ radicals (around $10^{7}$ molecules $\mathrm{cm}^{-3}$ ). This resulted in an immediate increase in the aerosol-corrected mass concentration by approximately $3 \mu \mathrm{g} \mathrm{m}^{-3}(17 \%)$.

The time series of the HR-ToF-AMS signals at $m / z 43$ and 44 for the same experiment (Experiment 31) are shown in Fig. 6. Chemical aging resulted in an increase of $f_{43}$ from 0.08 to 0.09 and of $f_{44}$ from 0.065 to 0.08 . Also, the ratio $f_{44}: f_{43}$ increased by approximately $10 \%$ when $\mathrm{OH}$ was introduced into the chamber. The $\mathrm{O}: \mathrm{C}$ ratio increased from 0.26 to 0.32 , after the production of the $\mathrm{OH}$ radicals in the chamber indicating chemical aging of $\beta$-caryophyllene SOA (Fig. 6c). The results of all aging experiments are summarized in Table 2 . The SOA yields increased by $10-30 \%$ because of the aging reactions.

Matsunaga and Ziemann (2010) and Zhang et al. (2014) have stressed the possibility of losses of vapors to the Teflon chamber walls. During chemical aging these compounds could be transformed to SOA, and therefore these vapor losses may be introducing significant negative artifacts in chemical aging experiments. In order to test this hypothe-
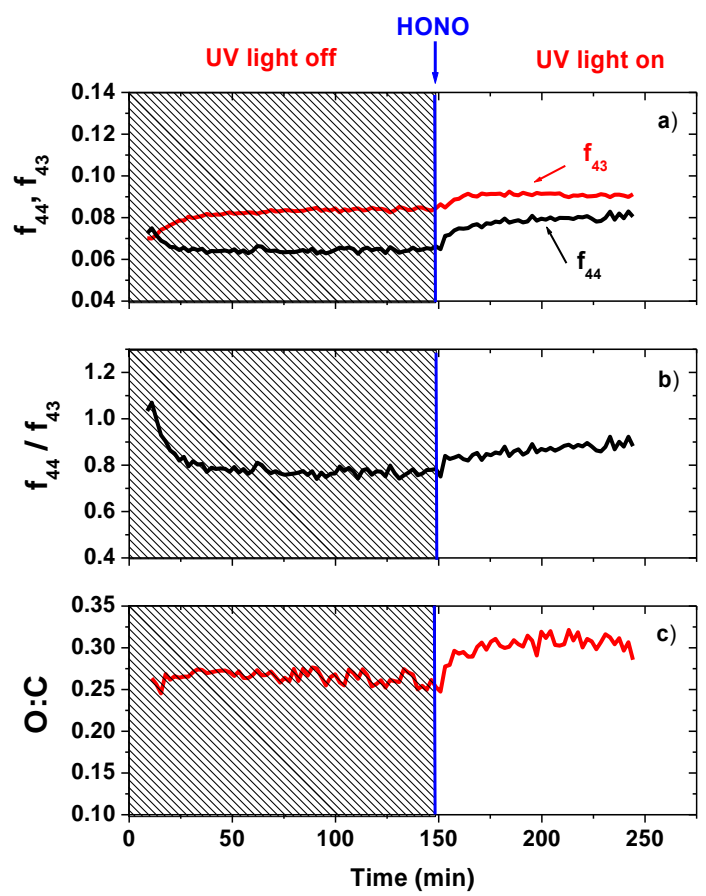

Figure 6. (a) The time series of fragments 43 and 44. (b) The ratio of the two fragments as a function of time. (c) The oxygen-tocarbon ratio of the particles as a function of time for Experiment 31. The shaded part indicates the period when the UV light was off, and the other section represents the period when the UV light was on. Also shown is the time when HONO was injected into the chamber.

sis, we conducted experiments in which the chemical aging of the SOA was initiated immediately after the SOA was formed. In Experiment 33 we initiated chemical aging of the $\beta$-caryophyllene SOA approximately $10 \mathrm{~min}$ after the maximum SOA mass concentration was reached instead of around $1.5 \mathrm{~h}$ later in other experiments. The chemical aging of the SOA resulted in a wall-loss-corrected SOA mass concentration increase from 31 to $41 \mu \mathrm{g} \mathrm{m}^{-3}$, i.e., approximately $32 \%$. The $\mathrm{O}: \mathrm{C}$ ratio increased from 0.26 to 0.29 . Gas-phase oxidation and transfer of the corresponding later-generation products to the particulate phase can probably explain the increase in SOA mass concentration and the change in $\mathrm{O}: \mathrm{C}$. However, we cannot eliminate the possibility of the existence of heterogeneous processes that also contribute to this increase. Studies in which the gas phase organic compounds were not present (or were present at much lower levels) are needed to separate the effects of homogeneous and heterogeneous reaction in the system. The results in Experiment 33 do support the wall loss of organic vapors to the walls.

To test the role of the RH, two experiments were performed under higher relative-humidity conditions, i.e., 50 and $90 \%$ (Experiments 34, 35). The SMPS sheath air flow was not dried, and therefore the SMPS measurements were at an RH similar and a little lower of that in the smog chamber. The hygroscopic growth of $\beta$-caryophyllene SOA has 


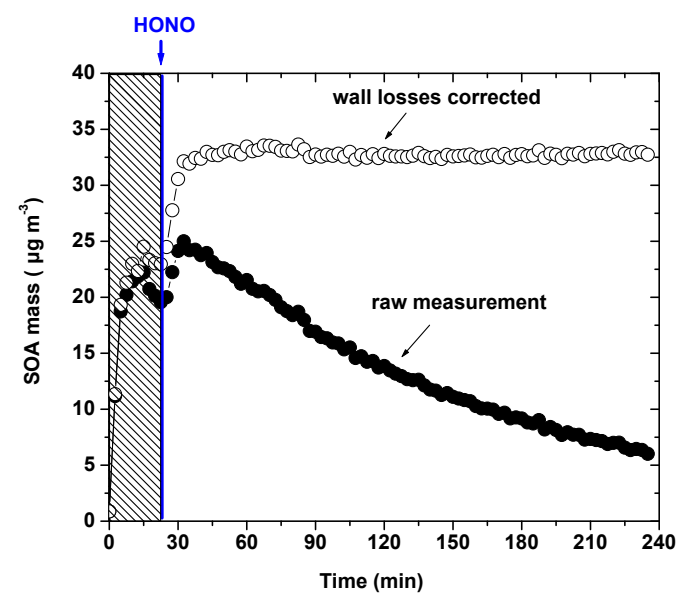

Figure 7. The measured aerosol mass concentration in the chamber as a function of time and the wall-loss-corrected SOA mass concentration (for $w=1$ ) (Experiment 35). The shaded part indicates the period when the UV light was off, and the other section represents the period when the UV light was on. Also shown is the time when HONO was injected into the chamber.

been investigated by Alfarra et al. (2012). The corresponding water uptake even at RH of $90 \%$ was low (diameter growth factor of 1.03 on average), and therefore any increase in the volume of the particles should be less than $10 \%$. The high relative humidity did not affect the SOA production and their chemistry; the SOA yield and the $\mathrm{O}: \mathrm{C}$ for this set of experiments were similar to the low relative-humidity experiments of these series. Our results are not consistent with those of Winterhalter et al. (2009). However, there are numerous experimental differences in the two studies, so it is difficult to draw any firm conclusions about what is causing this discrepancy. Figure 7 depicts the SOA mass concentration time series of Experiment 35. Ten minutes after the maximum SOA mass concentration was reached, the $\mathrm{OH}$ concentration in the chamber was increased by injecting HONO. The earlier maximum in Experiment 35 is mainly due to a much higher wall loss rate constant for this experiment compared to the others. It was $0.42 \mathrm{~h}^{-1}$ compared to $0.28 \mathrm{~h}^{-1}$ for Experiment 1 . These faster losses led to an earlier decline of the concentrations by $15 \mathrm{~min}$ or so compared to other experiments. In both Experiments 34 and 35, the chemical aging resulted in a $40 \%$ increase in the wall-loss-corrected mass concentration. The chemical aging of the $\beta$-caryophyllene SOA under high relative humidity resulted in the largest additional SOA mass production.

In experiments 36 and 37, we investigated the chemical aging of the $\beta$-caryophyllene SOA in the presence of $\mathrm{OH}$ radicals when photolysis of $\mathrm{H}_{2} \mathrm{O}_{2}$ was used as a source of $\mathrm{OH}$. In Experiment 36 the wall-loss-corrected SOA mass concentration of the fresh SOA was $30 \mu \mathrm{g} \mathrm{m}^{-3}$, and the $\mathrm{O}: \mathrm{C}$ was approximately 0.28 . Approximately $1.5 \mathrm{~h}$ after the mass of the SOA had started decreasing in the smog chamber, the

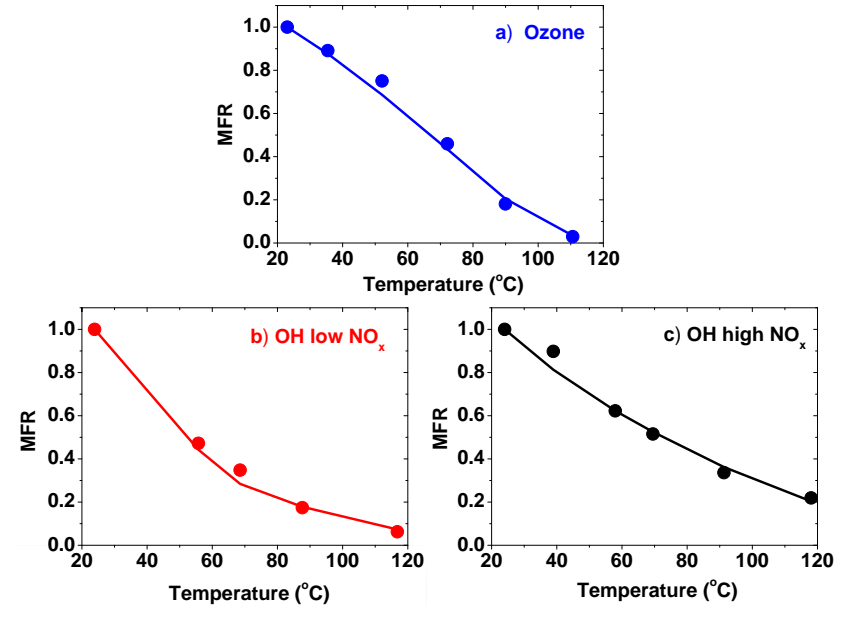

Figure 8. The thermograms (mass fraction remaining, MFR, as a function of temperature) of the three different reaction systems. The circles represent the experimental data, while the lines are the fitting of the model.

photolysis of $\mathrm{H}_{2} \mathrm{O}_{2}$ was initiated. The exposure of the SOA to $\mathrm{OH}$ radicals was 1 order of magnitude lower than in the previous aging experiments (Experiments 31-35). After the production of $\mathrm{OH}$ radicals the mass concentration of the SOA remained stable and the $\mathrm{O}: \mathrm{C}$ was 0.29 . The corresponding mass spectra of the organic aerosol mass at the periods before and after the $\mathrm{OH}$ radical production were practically the same $\left(\theta=3^{\circ}\right)$. Experiment 37 led to similar results.

\subsection{Vaporization enthalpy of $\beta$-caryophyllene SOA}

Using a thermodenuder we examined the behavior of the SOA at high temperatures. The mass fraction remaining (MFR) of SOA for the thermodenuder experiments is presented in Fig. 8. We used the volatility distributions of the reaction products estimated from the measured yields (Table 3) as inputs to the thermodenuder model described by Ripiinen et al. (2010) and estimated the vaporization enthalpy and the accommodation coefficient $(\alpha)$ of the $\beta$-caryophyllene SOA. For the particles that are produced from the ozonolysis of $\beta$-caryophyllene (Experiment 3 ), the calculated effective enthalpy of vaporization was $70 \pm 21 \mathrm{~kJ} \mathrm{~mol}^{-1}$ and $\alpha=0.03$. In other sets of simulations, the mass fraction remaining during the ramp of the temperature in the chamber (Experiment 1) was also used as input to the model. Finally, a combination of the two experiments was used. In all cases, the estimated enthalpy of vaporization and accommodation coefficient did not change. For $\beta$-caryophyllene reacted with $\mathrm{OH}$ in the presence of high concentrations of $\mathrm{NO}_{x}$ (Experiment 25), the SOA formed had an effective enthalpy of vaporization of $44 \pm 23 \mathrm{~kJ} \mathrm{~mol}^{-1}$ and $\alpha=0.08$. The SOA produced by the reaction with $\mathrm{OH}$ at low- $\mathrm{NO}_{x}$ concentration (Experiment 26) had an effective enthalpy of $56 \pm 21 \mathrm{~kJ} \mathrm{~mol}^{-1}$ and $\alpha=0.05$. 


\section{Conclusions}

In this study we examined the formation of secondary organic aerosol from the reaction of $\beta$-caryophyllene with $\mathrm{O}_{3}$ and $\mathrm{OH}$ radicals. The SOA yield for the ozonolysis of $\beta$ caryophyllene was $27 \%$ at $10 \mu \mathrm{g} \mathrm{m}^{-3} \mathrm{SOA}$. The measured yields are generally consistent with those reported by Chen et al. (2012). The average density of the SOA formed in the ozonolysis experiments was $0.99 \pm 0.05 \mu \mathrm{g} \mathrm{m}^{-3}$. The average $\mathrm{O}: \mathrm{C}$ ratio of the $\mathrm{SOA}$ produced was $0.31 \pm 0.04$, and the $\mathrm{H}$ : C ratio was $1.5 \pm 0.03$. These values were calculated with the Aiken et al. (2008) approach. Use of the Canagaratna et al. (2015) corrections increases the $\mathrm{O}: \mathrm{C}$ by approximately 0.2 units. The exposure of the $\beta$-caryophyllene SOA to UV light had no effect on the SOA.

The reaction of $\beta$-caryophyllene with $\mathrm{OH}$ at low $\mathrm{NO}_{x}$ gave an SOA yield equal to $20 \%$ at $10 \mu \mathrm{g} \mathrm{m}^{-3} \mathrm{SOA}$, similar to the SOA yield measured for the ozonolysis experiments. The average density of the SOA formed in these experiments was $1.05 \pm 0.04 \mu \mathrm{g} \mathrm{m}^{-3}$, the average $\mathrm{O}: \mathrm{C}$ ratio was $0.24 \pm 0.02$, and the $\mathrm{H}: \mathrm{C}$ ratio was $1.52 \pm 0.03$.

The SOA yield at the reaction of $\beta$-caryophyllene with $\mathrm{OH}$ at high $\mathrm{NO}_{x}$ was $38 \%$ at $10 \mu \mathrm{g} \mathrm{m}^{-3}$ SOA. The average density of the SOA formed in this series of experiments was $1.19 \pm 0.1 \mu \mathrm{g} \mathrm{m}^{-3}, 20 \%$ higher than the low- $\mathrm{NO}_{x}$ experiments. The average $\mathrm{O}: \mathrm{C}$ ratio was $0.34 \pm 0.07$, and the $\mathrm{H}$ : $\mathrm{C}$ ratio was $1.5 \pm 0.07$. While the reactions under low$\mathrm{NO}_{x}$ conditions had similar SOA yields to the ozonolysis reactions, the presence of high- $\mathrm{NO}_{x}$ levels leads to the production of less volatile compounds and to higher yields.

A series of chemical aging experiments were performed. During these experiments the SOA produced from the reaction of $\beta$-caryophyllene and $\mathrm{O}_{3}$ was exposed to $\mathrm{OH}$ radicals. The addition of $\mathrm{OH}$ radicals, under high- $\mathrm{NO}_{x}$ conditions, led to a $13-17 \%$ increase in SOA mass concentration in dry conditions, and the $\mathrm{O}: \mathrm{C}$ increased by 0.04 to 0.06 units. An experiment in which the chemical aging was initiated faster was conducted. The chemical aging of the SOA resulted in an SOA mass increase of $32 \%$, indicating that in this system the vapor losses to the Teflon chamber walls were not negligible. The exposure of the $\beta$-caryophyllene SOA to UV light and to hydroxyl radicals under low- $\mathrm{NO}_{x}$ conditions had little effect on the SOA.

We performed experiments with various amounts of seeds to estimate the magnitude of the vapor wall losses to the Teflon wall. We have also tried different reaction timescales (the longer the timescale, the higher the corresponding losses). Our conclusion is that there are such losses in the $\beta$-caryophyllene system, but they are modest (less than $30 \%$ in most cases).

A limited number of experiments was performed to investigate the role of $\mathrm{RH}$ in SOA formation and chemical aging. Experiments at 50 and $90 \% \mathrm{RH}$ were conducted, in which $\beta$-caryophyllene reacted with $\mathrm{O}_{3}$ in the presence of $\mathrm{OH}$ radicals. The high relative humidity did not appear to affect the fresh SOA production and its AMS spectrum. On the contrary, the high-RH conditions enhanced the chemical aging of the $\beta$-caryophyllene SOA. The exposure of SOA to $\mathrm{OH}$ radicals under high $\mathrm{NO}_{x}$ and high $\mathrm{RH}$ led to an increase in the SOA concentration by $40 \%$, and the $\mathrm{O}: \mathrm{C}$ increased by 0.07 units.

For the particles that are produced by the ozonolysis of $\beta$-caryophyllene, the calculated effective enthalpy of vaporization was $70 \pm 21 \mathrm{~kJ} \mathrm{~mol}^{-1}$, while for the experiments in which $\beta$-caryophyllene reacted with $\mathrm{OH}$ at low- $\mathrm{NO}_{x}$ conditions, it was $56 \pm 21 \mathrm{~kJ} \mathrm{~mol}^{-1}$, and at high- $\mathrm{NO}_{x}$ conditions, it was $44 \pm 23 \mathrm{~kJ} \mathrm{~mol}^{-1}$. In all cases, there was evidence of moderate resistances to mass transfer (mass accommodation coefficient: 0.03-0.08).

Acknowledgements. We would like to thank Eleni Karnezi for her help with the thermodenuder simulations and Evangelia Kostenidou for experimental advice. This study was supported by EPA STAR program (grant RD-835405) and the EU FP7 IDEAS ATMOPACS project.

Edited by: J. B. Burkholder

\section{References}

Aiken, A. C., DeCarlo, P. F., Kroll, J. H., Worsnop, D. R., Huffman, J. A., Docherty, K. S., Ulbrich, I. M., Mohr, C., Kimmel, J. R., Sueper, D., Sun, Y., Zhang, Q., Trimborn, A., Northway, M., Ziemann, P. J., Canagaratna, M. R., Onasch, T. B., Alfarra, M. R., Prevot, A. S. H., Dommen, J., Duplissy, J., Metzger, A., Baltensperger, U., and Jimenez, J. L.: O / C and OM / OC ratios of primary, secondary, and ambient organic aerosols with HighResolution Time-of-Flight Aerosol Mass Spectrometry, Environ. Sci. Technol., 42, 4478-4485, 2008.

Alfarra, M. R., Hamilton, J. F., Wyche, K. P., Good, N., Ward, M. W., Carr, T., Barley, M. H., Monks, P. S., Jenkin, M. E., Lewis, A. C., and McFiggans, G. B.: The effect of photochemical ageing and initial precursor concentration on the composition and hygroscopic properties of $\beta$-caryophyllene secondary organic aerosol, Atmos. Chem. Phys., 12, 6417-6436, doi:10.5194/acp12-6417-2012, 2012.

An, J. W., Pathak, K. R., Lee, B. H., and Pandis, S. N.: Aerosol volatility measurement using an improved thermodenuder: Application to secondary organic aerosol, J. Aerosol Sci., 38, 305314, 2007.

Atkinson, R. and Arey, J.: Gas-phase tropospheric chemistry of biogenic volatile organic compounds: a review, Atmos. Environ., 37, 197-219, 2003.

Canagaratna, M. R., Jimenez, J. L., Kroll, J. H., Chen, Q., Kessler, S. H., Massoli, P., Hildebrandt Ruiz, L., Fortner, E., Williams, L. R., Wilson, K. R., Surratt, J. D., Donahue, N. M., Jayne, J. T., and Worsnop, D. R.: Elemental ratio measurements of organic compounds using aerosol mass spectrometry: characterization, improved calibration, and implications, Atmos. Chem. Phys., 15, 253-272, doi:10.5194/acp-15-253-2015, 2015. 
Chan, M. N., Surratt, J. D., Chan, A. W. H., Schilling, K., Offenberg, J. H., Lewandowski, M., Edney, E. O., Kleindienst, T. E., Jaoui, M., Edgerton, E. S., Tanner, R. L., Shaw, S. L., Zheng, M., Knipping, E. M., and Seinfeld, J. H.: Influence of aerosol acidity on the chemical composition of secondary organic aerosol from $\beta$-caryophyllene, Atmos. Chem. Phys., 11, 1735-1751, doi:10.5194/acp-11-1735-2011, 2011.

Chen, Q., Liu, Y., Donahue, N. M., Shilling, J. E., and Martin, S. T.: Particle-phase chemistry of secondary organic material: Modeled compared to measured $\mathrm{O}: \mathrm{C}$ and $\mathrm{H}: \mathrm{C}$ elemental ratios provide constraints, Environ. Sci. Technol., 45, 4763-4770, 2011.

Chen, Q., Li, Y. L., McKinney, K. A., Kuwata, M., and Martin, S. T.: Particle mass yield from $\beta$-caryophyllene ozonolysis, Atmos. Chem. Phys., 12, 3165-3179, doi:10.5194/acp-12-31652012, 2012.

Crump, J. G. and Seinfeld, J. H.: Turbulent deposition and gravitational sedimentation of an aerosol in a vessel of arbitrary shape, J. Aerosol Sci., 12, 405-415, 1981.

Docherty, K. S., Jaoui, M., Corse, E., Jimenez, J. L., Offenberg, J. H., Lewandowski, M., and Kleindienst, T.E.: Collection efficiency of the aerosol mass spectrometer for chamber-generated secondary organic aerosols, Aerosol Sci. Tech., 47, 294-309, 2013.

Donahue, N. M., Robinson, A. L., Stanier, C. O., and Pandis, S. N.: Coupled partitioning, dilution and chemical aging of semivolatile organics, Environ. Sci. Technol., 40, 2635-2643, 2006.

Donahue, N. M., Henry, K. M., Mentel, T. F., Kiendler-Scharr, A., Spindler, C., Bohn, B., Brauers, T., Dorn, H. P., Fuchs, H., Tillmann, R., Wahner, A., Saathoff, H., Naumann, K. H., Möhler, O., Leisner, T., Müller, L., Reinnig, M. C., Hoffmann, T., Salo, K., Hallquist, M., Frosch, M., Bilde, M., Tritscher, T., Barmet, P., Praplan, A. P., DeCarlo, P. F., Dommen, J., Prévôt, A. S. H., and Baltensperger, U.: Aging of biogenic secondary organic aerosol via gas-phase $\mathrm{OH}$ radical reactions, P. Natl. Acad. Sci. USA, 109, 13503-13508, 2012.

Farmer, D. K., Matsunaga, A., Docherty, K. S., Surratt, J. D., Seinfeld, J. H., Ziemann, P. J., and Jimenez, J. L.: Response of an aerosol mass spectrometer to organonitrates and organosulfates and implications for atmospheric chemistry, P. Natl. Acad. Sci. USA, 107, 6670-6675, 2010.

Griffin, R. J., Cocker III, D. R., Flagan R. C., and Seinfeld, J. H.: Organic aerosol from the oxidation of biogenic hydrocarbons, J. Geophys. Res., 104, 3555-3567, 1999a.

Griffin, R. J., Cocker III, D. R., Seinfeld, J. H., and Dabdub, D.: Estimate of global atmospheric organic aerosol from oxidation of biogenic hydrocarbons, Geophys. Res. Lett., 26, 2721-2724, $1999 b$

Helmig, D., Bocquet, F., Pollmann, J., and Revermann, T.: Analytical techniques for sesquiterpene emission rate studies in vegetation enclosure experiments, Atmos. Environ., 38, 557-572, 2004.

Helmig, D., Ortega, J., Duhl, T., Tanner, D., Guenther, A., Harley, P., Wiedinmyer, C., Milford, J., and Sakulyanontvittaya, T.: Sesquiterpene emissions from pine trees-identifications, emission rates and flux estimates for the contiguous United States, Environ. Sci. Technol., 41, 1545-1553, 2007.

Hildebrandt, L., Henry, K. M., Kroll, J. H., Worsnop, D. R., Pandis, S. N., and Donahue, N. M.: Evaluating the mixing of organic aerosol components using High-Resolution Aerosol Mass Spectrometry, Environ. Sci. Technol., 45, 6329-6335, 2011.
Hoffmann, T., Odum, J. R., Bowman, F., Collins, D., Klockow, D., Flagan, R. C., and Seinfeld, J. H.: Formation of organic aerosol from oxidation of biogenic hydrocarbons, J. Atmos. Chem., 26, 189-222, 1997.

Jaoui, M., Leungsakul, S., and Kamens, R. M.: Gas and particle products distribution from the reaction of $\beta$-caryophyllene with ozone, J. Atmos. Chem., 45, 261-287, 2003.

Jaoui, M., Kleindienst, T. E., Docherty, K. S., Lewandowski, M., and Offenberg, J. H.: Secondary organic aerosol formation from the oxidation of a series of sesquiterpenes: a-cedrene, bcaryophyllene, a-humulene and a-farnesene with $\mathrm{O}_{3}, \mathrm{OH}$ and $\mathrm{NO}_{3}$ radicals, Environ. Chem., 10, 178-193, 2013.

Kanakidou, M., Seinfeld, J. H., Pandis, S. N., Barnes, I., Dentener, F. J., Facchini, M. C., Van Dingenen, R., Ervens, B., Nenes, A., Nielsen, C. J., Swietlicki, E., Putaud, J. P., Balkanski, Y., Fuzzi, S., Horth, J., Moortgat, G. K., Winterhalter, R., Myhre, C. E. L., Tsigaridis, K., Vignati, E., Stephanou, E. G., and Wilson, J.: Organic aerosol and global climate modelling: a review, Atmos. Chem. Phys., 5, 1053-1123, doi:10.5194/acp-5-1053-2005, 2005.

Knudsen, J. T., Tollsten, L., and Bergström, L. G.: Review Article Number 76: Floral scents-a checklist of volatile compounds isolated by head-space techniques, Phytochemistry, 33, 253-280, 1993.

Kostenidou, E., Pathak, R. K., and Pandis, S. N.: An algorithm for the calculation of secondary organic aerosol density combining AMS and SMPS data, Aerosol Sci. Technol., 41, 1002-1010, 2007.

Kostenidou, E., Lee, B. H., Engelhart, G. J., Pierce, J. R., and Pandis, S. N.: Mass spectra deconvolution of low, medium, and high volatility biogenic secondary organic aerosol, Environ. Sci. Technol., 43, 4884-4889, 2009.

Lane, T., Donahue, N. M., and Pandis, S. N.: Simulating secondary organic aerosol formation using the basis-set approach in a chemical transport model, Atmos. Environ., 42, 7439-7451, 2008.

Lee, A., Goldstein, A. H., Keywood, M. D., Gao, S., Varutbangkul, V., Bahreini, R., Ng, N. L., Flagan, R. C., and Seinfeld, J. H.: Gas-phase products and secondary aerosol yields from the ozonolysis of ten different terpenes, J. Geophys. Res., 111, D07302, doi:10.1029/2005JD006437, 2006a.

Lee, A., Goldstein, A. H., Kroll, J. H., Ng, N. L., Varutbangkul, V., Flagan, R. C., and Seinfeld, J. H.: Gas-phase products and secondary aerosol yields from the photoxidation of 16 different terpenes, J. Geophys. Res., 111, D17305, doi:10.1029/2006JD007050, 2006b.

Li, Y. J., Chen, Q., Guzman, M. I., Chan, C. K., and Martin, S. T.: Second-generation products contribute substantially to the particle-phase organic material produced by $\beta$-caryophyllene ozonolysis, Atmos. Chem. Phys., 11, 121-132, doi:10.5194/acp11-121-2011, 2011.

Matsunaga, A. and Ziemann, P. J.: Gas-wall partitioning of organic compounds in a Teflon film chamber and potential effects on reaction product and aerosol yield measurements, Aerosol Sci. Tech., 44, 881-892, 2010.

Ng, N. L., Kroll, H. J., Keywood, D. M., Bahreini, R., Varutbangkul, V., Flagan, R. C., and Seinfeld J. H.: Contribution of first- versus second-generation products to secondary organic aerosols formed in the oxidation of biogenic hydrocarbons, Environ. Sci. Technol., 40, 2283-2297, 2006. 
Ng, N. L., Chhabra, P. S., Chan, A. W. H., Surratt, J. D., Kroll, J. H., Kwan, A. J., McCabe, D. C., Wennberg, P. O., Sorooshian, A., Murphy, S. M., Dalleska, N. F., Flagan, R. C., and Seinfeld, J. H.: Effect of $\mathrm{NO}_{x}$ level on secondary organic aerosol (SOA) formation from the photooxidation of terpenes, Atmos. Chem. Phys., 7, 5159-5174, doi:10.5194/acp-7-5159-2007, 2007.

Odum, J. R., Hoffmann, T., Bowman, F., Collins, D., Flagan, R. C., and Seinfeld J. H.: Gas/particle partitioning and secondary organic aerosol yields, Environ. Sci. Technol., 30, 2580-2585, 1996.

Offenberg, J. H., Lewandowski, M., Edney, E. O., Kleindienst, T. E., and Jaoui, M.: Influence of aerosol acidity on the formation of secondary organic aerosol from biogenic precursor hydrocarbons, Environ. Sci. Technol., 43, 7742-7747, 2009.

Pathak, R. K., Stanier, C. O., Donahue, N. M., and Pandis S. N.: Ozonolysis of a-pinene at atmospherically relevant concentrations: Temperature dependence of aerosol mass fractions (yields), J. Geophys. Res., 112, D03201, doi:10.1029/2006JD007436, 2007.
Riipinen, I., Pierce, J. R., Donahue N. M., and Pandis, S. N.: Equilibration time scales of organic aerosol inside thermodenuders: Kinetics versus equilibrium thermodynamics, Atmos. Environ., 44, 597-607, 2010.

Shu, Y. H. and Atkinson, R.: Atmospheric lifetimes and fates of a series of sesquiterpenes, J. Geophys. Res., 100, 7275-7281, 1995.

Winterhalter, R., Herrmann, F., Kanawati, B., Nguyen, T. L., Peeters, J., Vereeckenb L., and Moortgata G. K.: The gas-phase ozonolysis of b-caryophyllene $\left(\mathrm{C}_{15} \mathrm{H}_{24}\right)$. Part I: an experimental study, Phys. Chem. Chem. Phys., 11, 4152-4172, 2009.

Zhang, X., Cappa, D. C., Jathar, S. H., McVay, R. C., Ensberg, J. J., Kleeman, M. J., and Seinfeld, J. H.: Influence of vapor wall loss in laboratory chambers on yields of secondary organic aerosol, $\mathrm{P}$. Natl. Acad. Sci. USA, 111, 5802-5807, 2014. 